\title{
GARDEN PROFILE: THE NATIONAL BOTANIC GARDEN OF NEPAL
}

\author{
Kate Hughes ${ }^{1} \&$ Dipak Lamichhane ${ }^{2}$
}

\begin{abstract}
The National Botanic Garden of Nepal (NBG) lies 16km south of Kathmandu, at the base of Phulchowki, the highest mountain in the Kathmandu Valley. It was inaugurated in 1962 by King Mahendra and since that time the collections have developed, many of them into named areas and groupings. The year 2016 was the bicentenary of the establishment of diplomatic relations between Nepal and Great Britain, and this was marked in the NBG with the development of a Biodiversity Education Garden. This was created in collaboration with the Royal Botanic Garden Edinburgh (RBGE), and the occasion signified a revitalisation of collaborative relations between the NBG and British botanic gardens which started in the early 1960s with the appointment to NBG of British horticulturists Geoffrey Herklots and, later, Tony Schilling. The history of the garden, its layout and collections, and the activities and outcomes of the recent collaborations are described and illustrated with colour photographs.
\end{abstract}

\section{INTRODUCTION}

The National Botanic Garden of Nepal (NBG) covers an area of 82ha in the Kathmandu Valley, which is in the temperate zone of Nepal at an altitude of $1,515 \mathrm{~m}$. It lies at the base of the largest mountain in the Valley, Phulchowki $(2,765 \mathrm{~m})$ and is surrounded by forests of Alnus nepalensis, Schima wallichii, Quercus semecarpifolia and Castanopsis indica. Annual rainfall averages $1,900 \mathrm{~mm}, 80$ per cent of which falls between July and September when temperatures are also at their highest, reaching up to $30^{\circ} \mathrm{C}$ in the day. Temperatures drop to the extent that there can be an occasional light frost at night in late December and January but even in these months they can rise to $20^{\circ} \mathrm{C}$ during the day. These environmental conditions and the rich, slightly acidic soil of $\mathrm{pH} 5.8$ mean that the NBG is the ideal place for growing hardier sub-tropical and warm temperate plants.

Approximately 300,000 people visit the garden each year and it is relatively accessible from the city. Many of the visitors are schoolchildren brought by school bus from Kathmandu, where there is little open or green space, for an opportunity to get some fresh air, play and have a picnic (Fig. 1). The garden is known for the variety of birdlife it supports due to the diversity of environments and topography in the area. Many visitors, particularly foreign tourists, bring binoculars and look for birds as well as plants (Fig. 2).

1. Kate Hughes is a Senior Horticulturist and Sub Editor of Sibbaldia at the Royal Botanic Garden Edinburgh, and is the corresponding author for this paper.

Address: 20A Inverleith Row, Edinburgh, EH3 5LR, UK.

Email: K.Hughes@rbge.org.uk

2. Dipak Lamichhane is Senior Garden Officer of the National Botanic Garden of Nepal.

Address: Postbox no: 3708. Godawari, Lalipur, Nepal. 


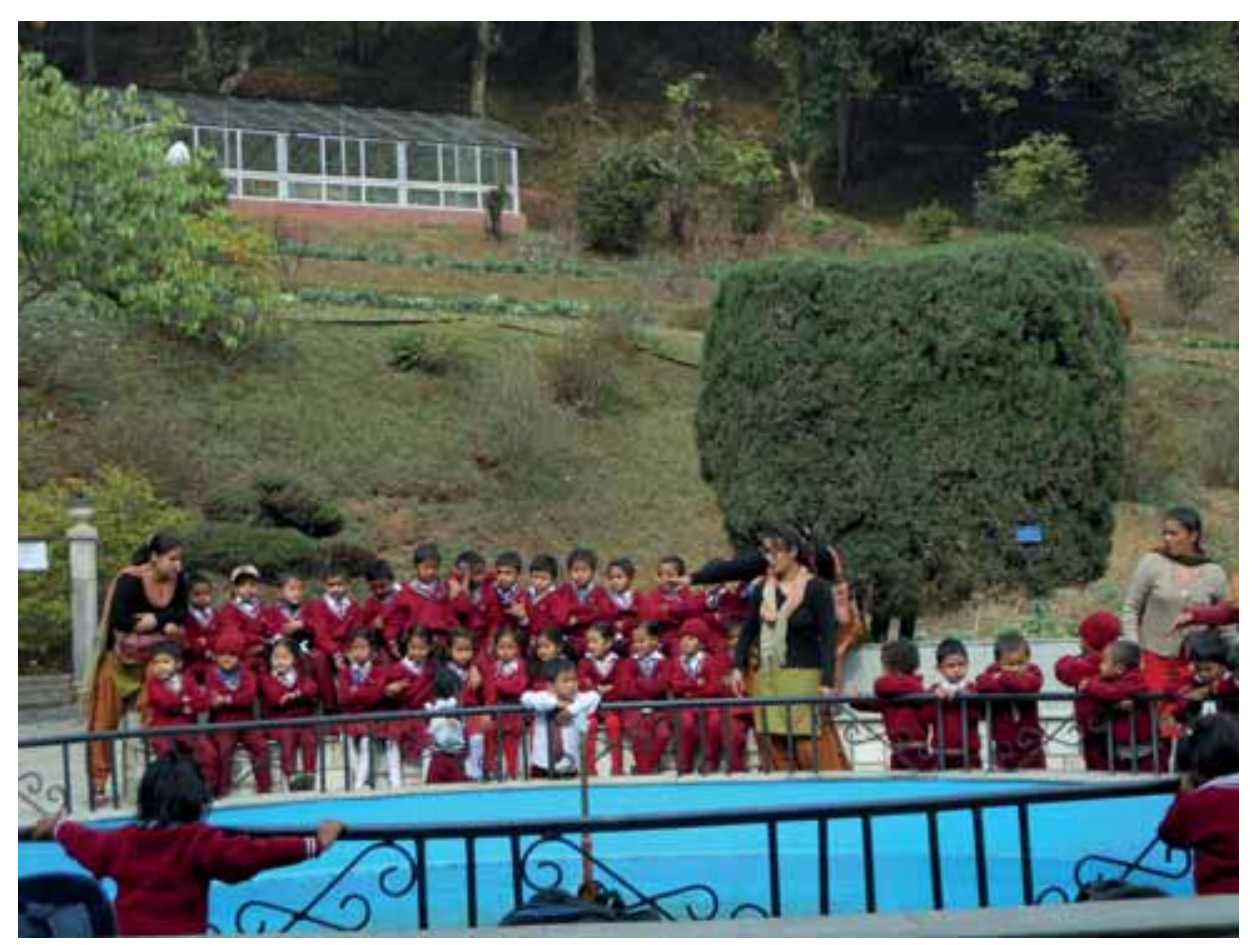

Fig. 1 Hundreds of schools with pupils of all ages visit the garden each year. Photo: Kate Hughes.

ORIGINS AND ORGANISATION OF THE NATIONAL BOTANIC GARDEN, NEPAL

The origins of the NBG are closely linked with British botanic gardens and institutions. It was established and inaugurated by the late King Mahendra Bir Bikram Shah Dev on 20 October 1962. He returned to Nepal after a visit to the UK in 1960 with an explicit desire to create a garden. He declared that he had been inspired by his official visit to the Royal Botanic Garden Edinburgh (RBGE), where he had planted a tree, and set about looking for a suitable site. A piece of land near the village of Godavari, about 16km south of Kathmandu in the district of Lalitpur and at the base of Phulchowki, was chosen with the assistance of Geoffrey Herklots. The management of the garden came under the Department of Medicinal Plants, Ministry of Forests, His Majesty's Government of Nepal. The land already had some Government-owned buildings on it which were used for administration space and some staff accommodation. These institutions are now called the Department of Plant Resources (DPR) and the Ministry of Forest and Soil Conservation, and the Government is no longer 'His Majesty's', but otherwise the organisational structure is similar to that in 1962. The DPR manages a further 11 smaller botanic gardens in Nepal along with the National Herbarium and Plant Laboratories (KATH) and the Natural Products Research Laboratory (NPRL) in Kathmandu. 


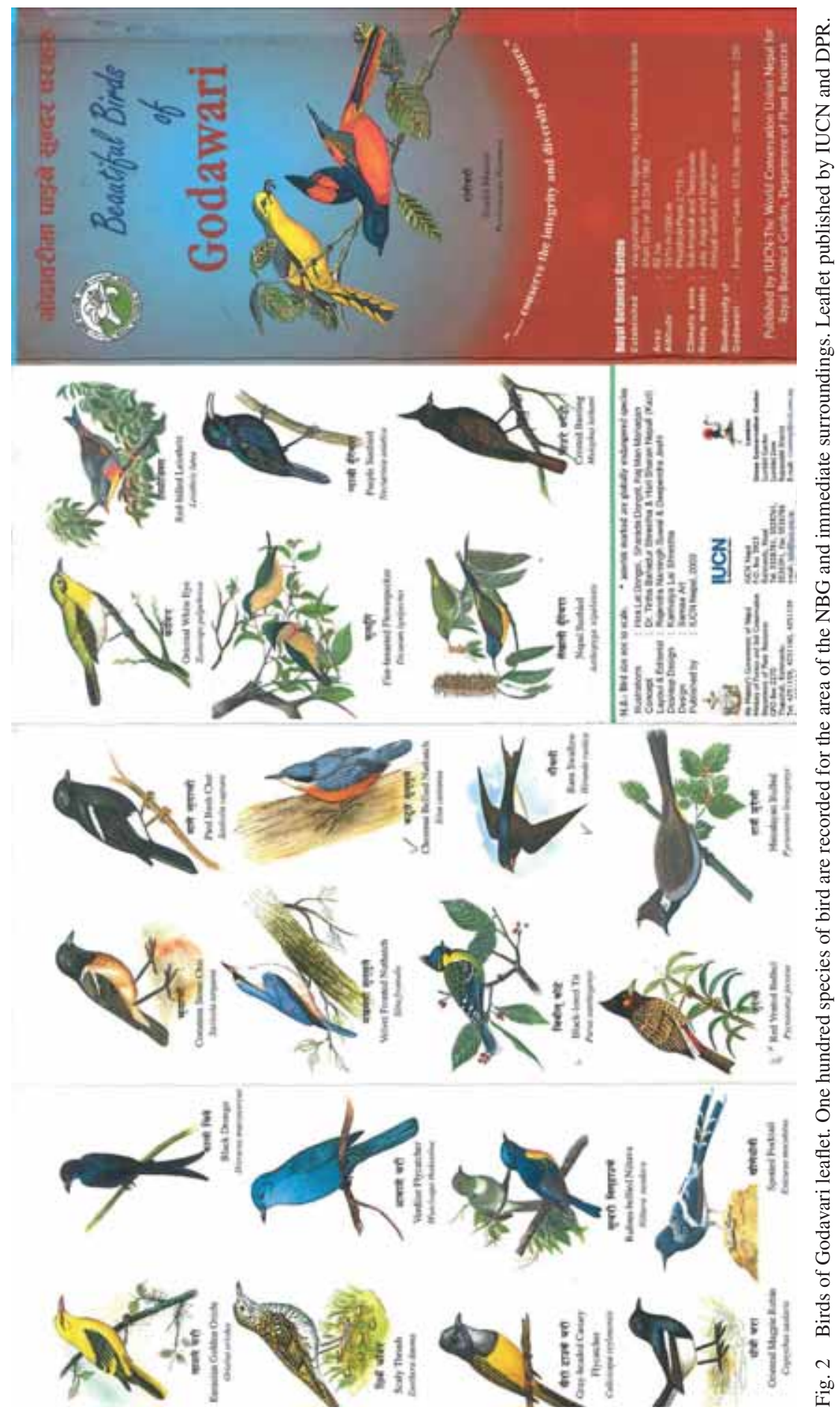


On its creation, the NBG was run by botanists who worked in the Department of Medicinal Plants, but British horticultural botanists were invited to advise on its establishment (Schilling, 1968). Geoffrey Herklots, a natural historian, orchid specialist, illustrator and architect with broad interests, spent two years of his retirement as advisor to the Nepalese Government (Holttum, 1986). He was present at the inauguration in 1962 and played an important role in the design and landscaping of what is now known as the Special Garden. He designed and built the gravity-fed water fountain, path system and some of the glasshouses there.

Tony Schilling, horticulture student and later staff member at the Royal Botanic Gardens, Kew (RBG, Kew), had a particular interest in alpine plants, and was seconded as technical advisor to the Nepalese Government after Herklots. Charged not only with developing the landscape of the garden at Godavari but also collecting and establishing native plants there, he did so diligently over his two-year placement in 1965-1966, most notably creating the Rock Garden, whose huge rocks were manipulated into place by elephants as well as humans (T Schilling, pers. comm.). He planted many Nepalese species, some of which form impressive specimens that make an important contribution to the views today. In addition, he designed and constructed two glasshouses on the upper slopes of the Special Garden, which now house cacti, cyclamen and other display plants (Fig. 3).

Today, the NBG is managed by Senior Garden Officer Dipak Lamichhane, assisted by the Senior Garden Officer, Srijana Shah, and Assistant Botanist, Kamal Nepali (Fig. 4). There are three sections within the garden - the Garden Development section, the Conservation and Educational Garden section and the Information, Production and Sales section - and a total of thirty-eight staff. The majority of these are horticultural staff in the Garden Development Section and the Conservation and Educational Garden Section.

\section{LAYOUT OF THE GARDEN}

The relatively large acreage of the garden means that some areas are highly managed and contain collections built up over time while others are less managed and more 'wild'. Fig. 5 shows the map of the garden presented to visitors on arrival. The landscaped areas and collections which feature on it are listed below:

\section{Botanical information and exhibition centre}

This is located at the entrance to the garden and displays posters on how plants function, the ecology of Nepal, and important plants for Nepal and the biodiversity associated with them. There is also a restaurant above the information centre. 


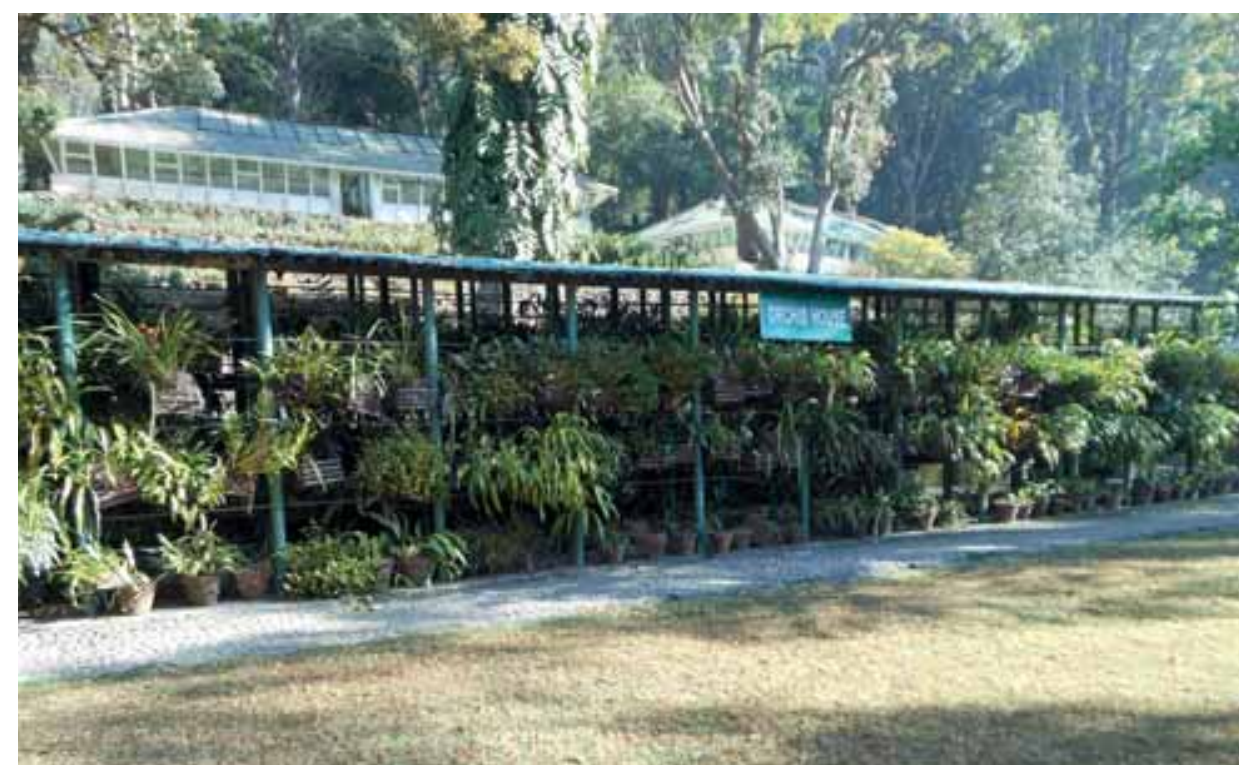

Fig. 3 Orchid House in the Special Garden showing the Temple Houses in the background designed and built by Tony Schilling in 1966. Photo: Kate Hughes.

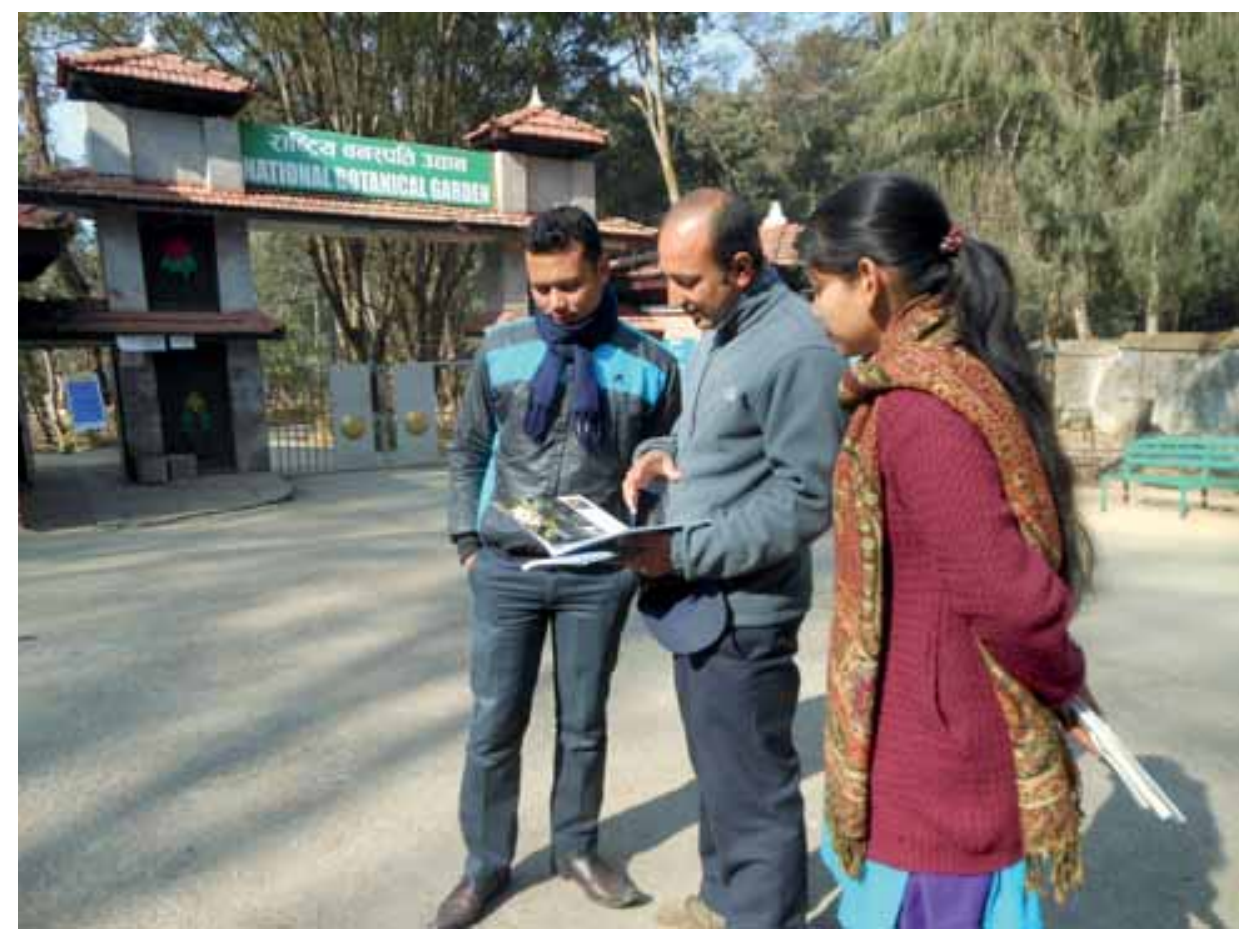

Fig. 4 Senior Garden Officers Dipak Lamichhane (centre) and Srijana Shah (right), and Assistant Botanist Kamal Nepali (left), at the main entrance to the NBG. Photo: Kate Hughes. 


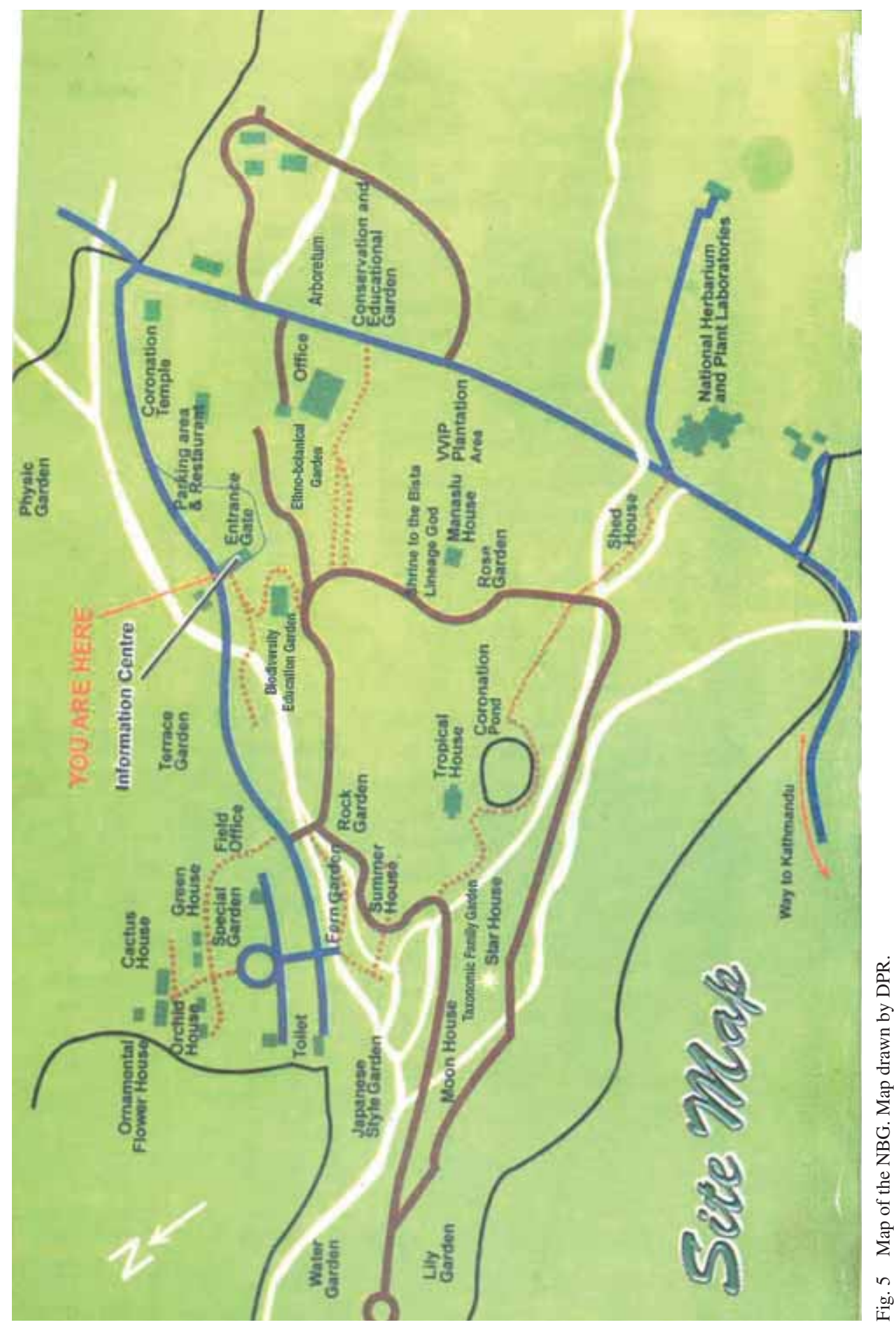




\section{Physic garden}

Approximately 70 species of medicinal and aromatic plants, many of which are used in Nepal, are grown here in distinct beds, and many are labelled.

\section{Biodiversity Education Garden (BEG)}

This area was developed in recognition of 200 years of diplomatic relations between Great Britain and Nepal, and was formally opened in September 2016. Over seventy species of plants native to Nepal are displayed over three ecological zones and interpreted with twenty-nine information panels. See below for more information on this area.

\section{Special Garden}

This is one of the most popular areas of the garden thanks to its ornamental displays and glasshouses. It lies on a slope which gives good views of the ornamental beds and water fountain pond (Fig. 6). The Orchid, Cyclamen and Cactus Houses are at the top of the slope in the Special Garden. These were designed and built by Tony Schilling in 1966.

\section{Terrace Garden}

This is also known as the Nepalese Style Garden and houses many native plants.

\section{Fern Garden}

This is another very popular area, not only for its proximity to the Special Garden but for the photo opportunities, shade and atmosphere offered by the mature Cyathea spinulosa plants, approximately $5 \mathrm{~m}$ high, and the shallow stream running through it. There is also a recently renovated shelter structure for displaying ferns in pots. Species displayed here include Pteris cretica, Polystichum squarrosum, Conigramme sp., Polystichum lentum and Agalaomorpha coronans (Fig. 7).

\section{Japanese Style Garden}

Here Camellia, Chaenomeles, Azalea and Acer cultivars are planted around Japanesestyle paths and the stream which runs through this part of the garden. Carefully placed rocks and boulders also feature here and grass is kept short around them, in the Japanese style of gardening. 
Fig. 6 Water fountain pond in the Special Garden showing the Senior Garden Officer's accommodation in the background. Photo: Kate Hughes.

Fig. 7 Cyathea spinulosa in the Fern Garden. Photo: Andrew Ensoll.
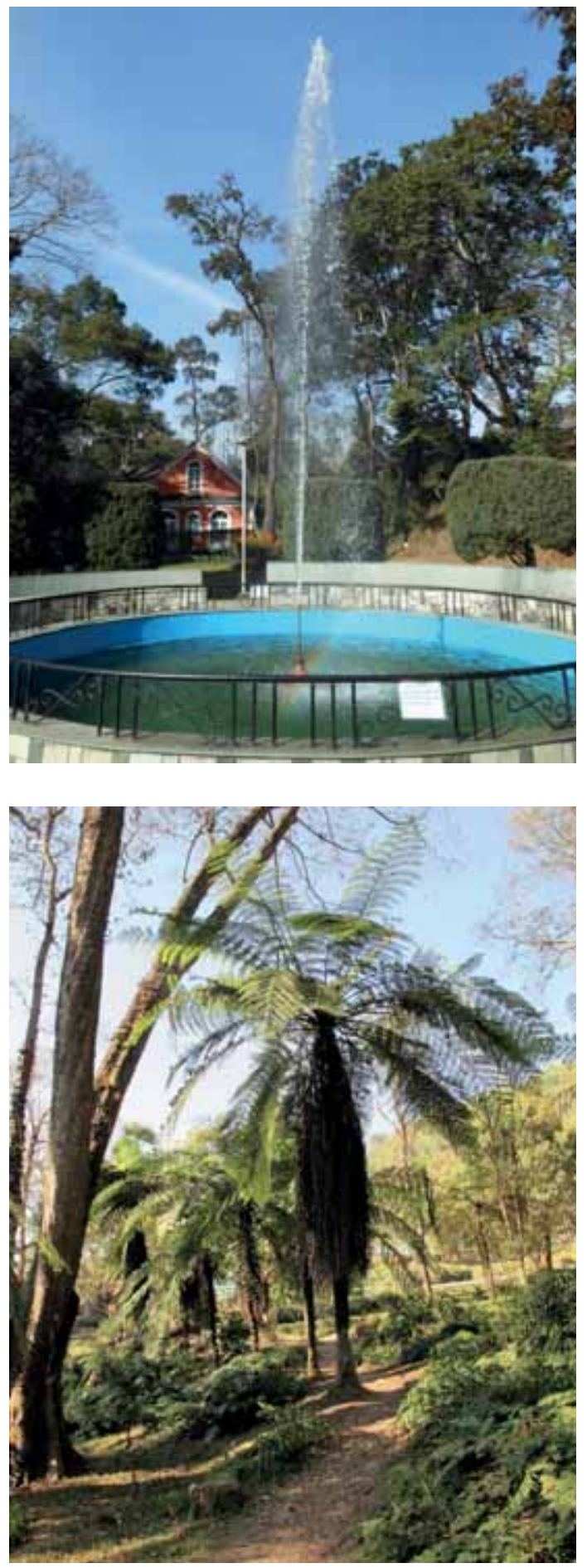


\section{Lily Garden}

Monocotyledonous plants such as Agapanthus, Hemerocallis, Iris and Lycoris are planted in blocks. These are very popular in the monsoon season months (June to August) because they make striking displays when in flower.

\section{Rock Garden}

This area was developed by Tony Schilling and lies adjacent to the BEG. The large rocks with plants growing around are very popular with visitors for sitting on. Shrubs including Chaenomeles japonica, Jasminum nudicaule, Thysanolaena latifolia and Aloe sp. are planted here (Fig. 8).

\section{Tropical House}

This glasshouse was built in 1974; it has a floor area of $294 \mathrm{~m}^{2}$ and is $12 \mathrm{~m}$ in height. In front of the Tropical House is the Coronation Pond, with a $7 \mathrm{~m}$ pillar commemorating the coronation of King Birendra Bir Bikram Shah in 1975. Important tropical plants are conserved inside this house (Sharma, 2003).

\section{VVIP Plantation Area}

This is a flat grassed area dedicated to plantings made by heads of state on their visits to Nepal (Fig. 9). The first planting was made by Marshal Tito, the then President of the Socialist Federal Republic of Yugoslavia. He planted a specimen of Rhododendron arboreum, the national flower of Nepal, in February 1974. In 1986, Queen Elizabeth II planted a female Ilex excelsa and her husband the Duke of Edinburgh planted a male plant of the same species. The most recent planting was of Taxus wallichiana var. mairei, made by the President of Nepal on the occasion of the inauguration of the BEG in September 2016.

Also in this area are the Rose Garden and the Manaslu House, a roofed shelter from which the Himalayan peak of Manaslu used to be visible in the distance before the many self-seeded Alnus nepalensis trees grew to maturity and somewhat obscured the view. The Tropical House described above is also visible from this viewpoint.

\section{Conservation and Educational Garden}

This is primarily a nursery area detached from the main garden and it is not open to the public. It was previously known as the Arboretum and lies next to the National Herbarium, which is located about $200 \mathrm{~m}$ along the main road from the NBG offices. It has a range of mature specimens and up to 90 different tree species planted. There are shade and poly structures for the protection of plants and outdoor planting beds. It is 


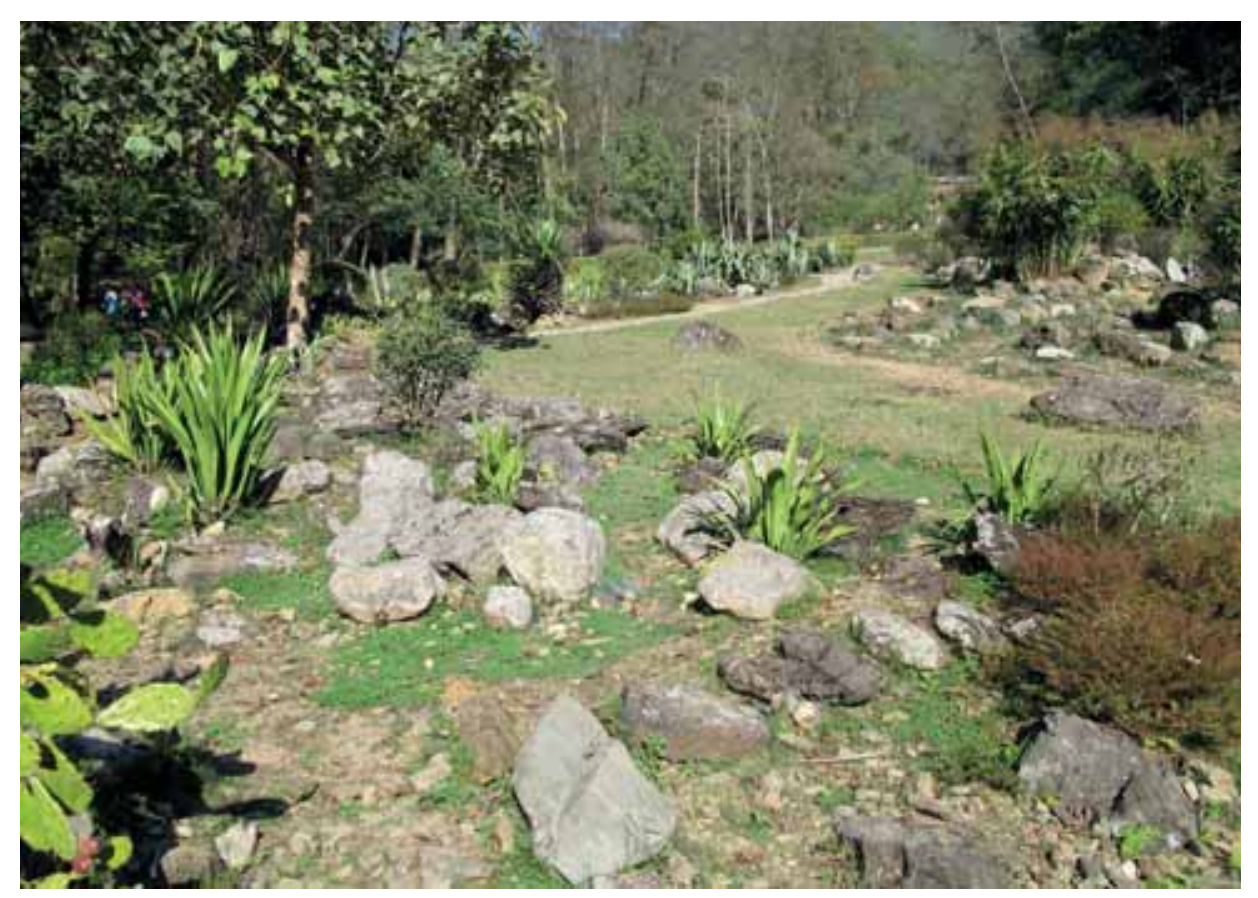

Fig. 8 The Rock Garden. Photo: Andrew Ensoll.

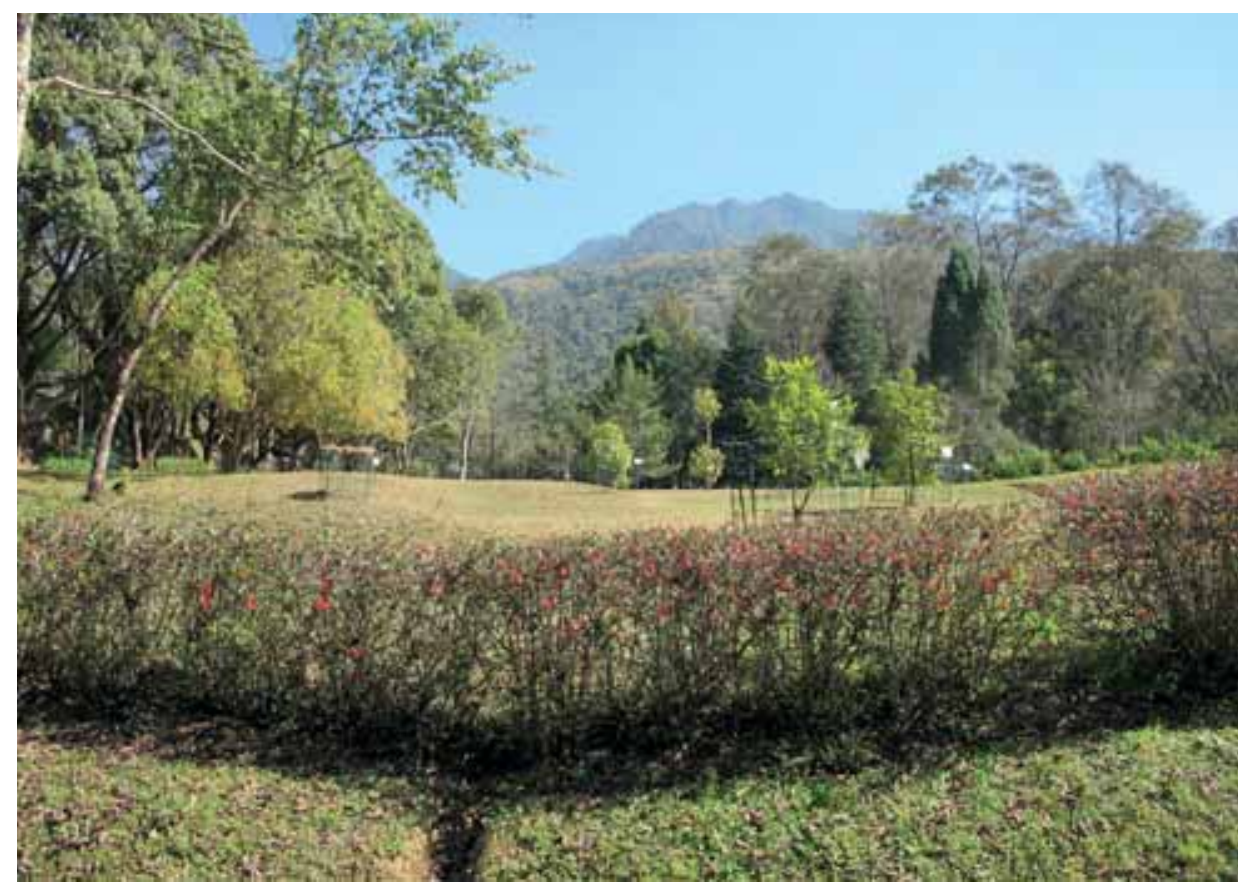

Fig. 9 The VVIP Plantation with Phulchowki mountain in the background. Photo: Andrew Ensoll. 
stocked from collections made by staff on field collection trips, and plants are used for research and education purposes.

\section{Taxonomy and Family Garden}

This area was created in 2016 and is used to demonstrate botanical orders and families, in particular for botanical students but also for the visiting public. Plantings are laid out in formal beds in accordance with the Bentham and Hooker system of classification.

\section{TWO HUNDRED YEARS OF NEPAL-UK RELATIONS}

In December 1815, the Anglo-Nepalese Treaty of Sugauli was signed, marking the end of the war between the Kingdom of Nepal and Great Britain's East India Company; among other things, it establishes the recruitment of Gurkha soldiers into the British Army.

This 200-year relationship was celebrated in Britain and Nepal throughout 2016, starting with an opening ceremony at the Foreign and Commonwealth Office in London on 15 December 2015. The British Embassy in Kathmandu and the Government of Nepal awarded funds for a collaborative project to deliver training and refurbish an area of the NBG which would be landscaped, planted with Nepalese native plants and fully interpreted with information panels, in order to provide an outdoor classroom to showcase the flora and habitats of Nepal. The project was the result of collaboration between science and horticulture staff from RBGE and DPR (NBG) staff. The Taxonomy and Family Garden was also created in 2016, and the plantings in the Tropical House were rejuvenated.

\section{Britain-Nepal Bicentenary Expedition to Rasuwa (BRAW)}

As part of the bicentenary celebrations a collaborative field trip to collect seed and plants from the Langtang region of Nepal took place in September 2016 just before the inauguration of the BEG. The DPR and RBGE staff on this two-week trip made 305 collections of sub-tropical, temperate and alpine species of flowering plants and ferns over an elevational range of 1,400-4,500m. Two sets of herbarium and seed and spore collections were made, with the first set of specimens deposited at the DPR and the second set at RBGE (Figs 10 \& 11). The seed and spore collections have resulted in a significant increase in the number of wild-collected species with comprehensive provenance data for both institutions and will form an important part of their collections. Once grown on, the plants will be planted in the BEG to ensure that the collection continues to develop and improve. 
Fig. 10 Collection of herbarium specimens and seed, Sing Gompa, Langtang.

Photo: Kate Hughes.
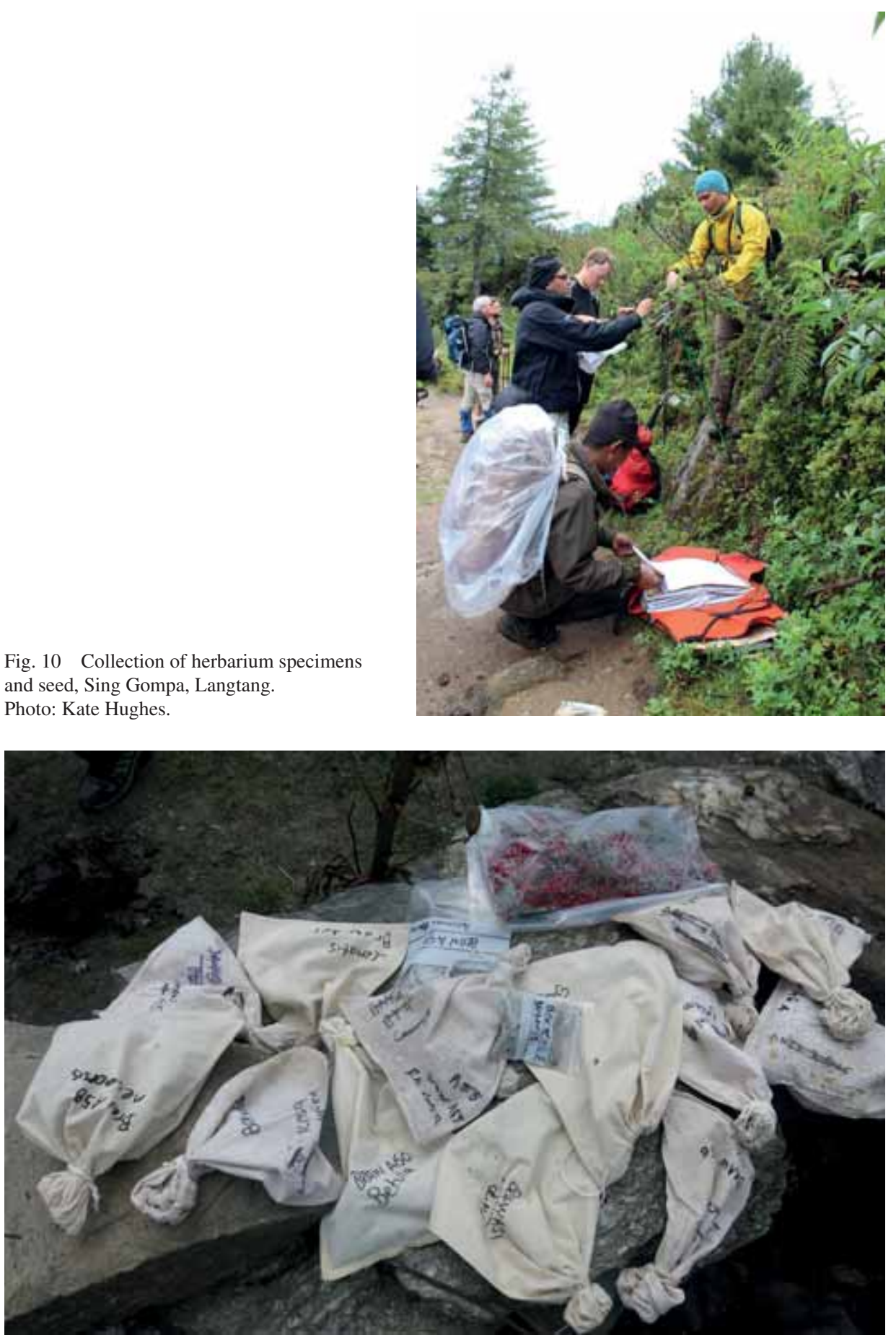

Fig. 11 Tree seed collected in bird bags and numbered. Photo: Mark Watson. 


\section{THE BIODIVERSITY EDUCATION GARDEN}

The Biodiversity Education Garden is prominently situated to the right of the main entrance gate and is therefore an excellent location to attract visitors. Formerly the area was unappealing to walk through despite the presence of a stone path because it was partially waterlogged with several dead tree stumps and was therefore relatively unused.

The BEG covers an area of 1.3ha and represents three ecological zones: alpine, temperate and tropical. Over 70 species of Nepalese plants are planted there (see Appendix 1), with 29 information panels on individual plant species (see Appendix 2) and the diverse ecology of Nepal. It has an extensive path system suitable for wheelchairs and pushchairs as well as pedestrians, and paved areas where large groups can gather. All the information panels include QR codes which take the reader to further information about the species or landscape on the Biodiversity Education Garden website (Biodiversity Education Garden, 2016). It was constructed by NBG and RBGE staff, working with local contractors and craftsmen. In September 2016, the garden was formally inaugurated by the President of Nepal, Mrs Bidya Devi Bhandari.

The interpretation and information boards are an important resource for visitors (Figs $12 \& 13$ ). There is very little readily available information about Nepalese plants either in the garden or in the wider community, and this interpretation includes attractive photographs as well as information on the names, habitats and uses of the plants in two languages. Plants are, of course, a fundamental part of Nepalese life and culture but so familiar are many of them that there is not necessarily widespread appreciation for the crucial role they play. In addition, there is a lack of awareness of the threats that many species face with increasing climate and land use change. The BEG aims to improve awareness of these threats to the landscape of Nepal.

The concept of the BEG was first discussed in December 2014 between the Curator of the NBG, the British Ambassador to Nepal at the time, Mr Andrew Sparkes, and Mark Watson of RBGE as part of discussions as to how the bicentenary could be celebrated in a way which would create a resource for the future. In January 2015, staff from RBGE made a scoping visit to the site and the proposal was firmed up. In March of the same year, practical horticultural training was delivered to the NBG in preparation for making and maintaining the new garden area. The training was based on the model and materials used in the Certificate in Practical Horticulture (CPH), developed by RBGE and run in Edinburgh and ten other venues throughout the UK. The course teaches practical horticultural skills using exercises augmented with demonstrations, and all of the classes are held in the nursery or garden rather than a traditional classroom (see Morris \& Cohen, 2010, and RBGE, 2017 for more information about the CPH).

In June 2015, final approval was given for the project. This followed uncertainty about its future because of the pressures put on the country after the massive earthquake of April 2015. Work started in earnest in July 2015 when RBGE and NBG staff began to remove obsolete and non-native trees and shrubs. This continued in October 2015 when RBGE staff travelled to Nepal, and on this occasion they also collected plants and seeds 


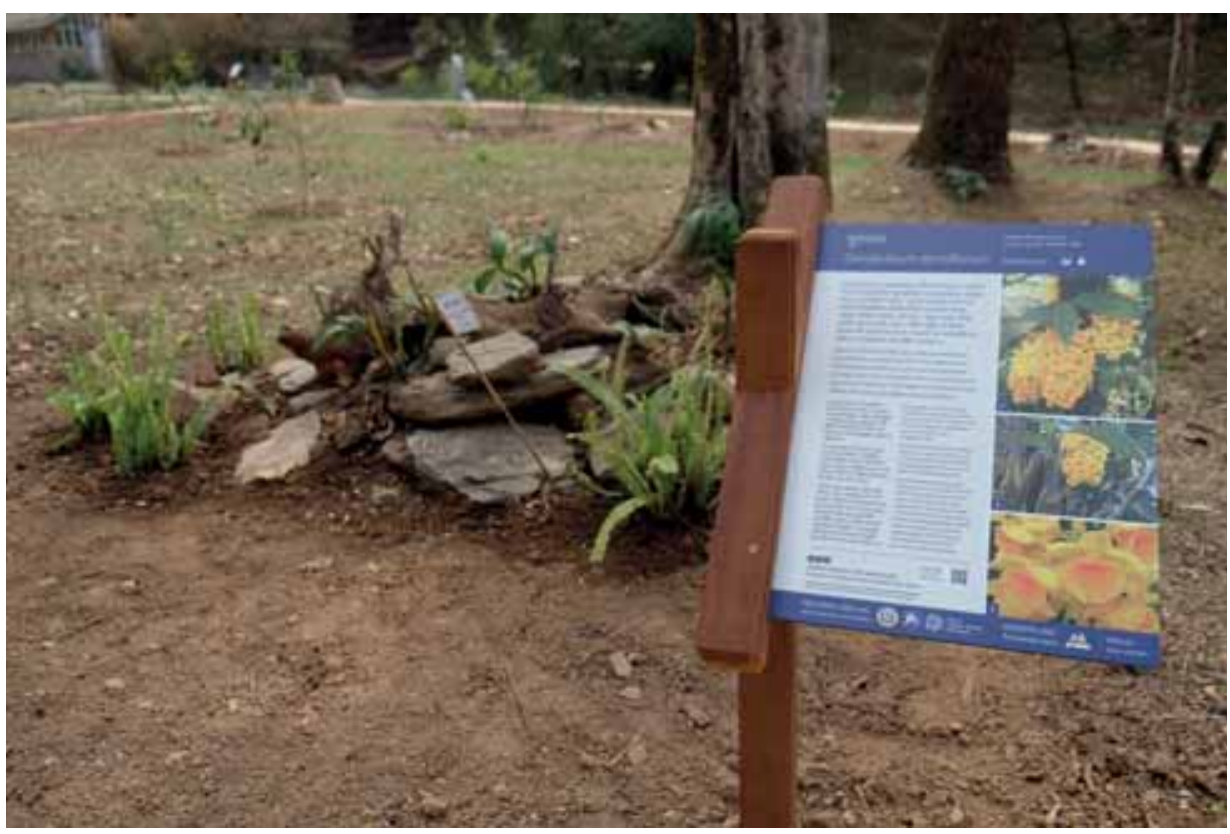

Fig. 12 The feature plant panel for Dendrobium densiflorum. Photo: Nye Hughes.

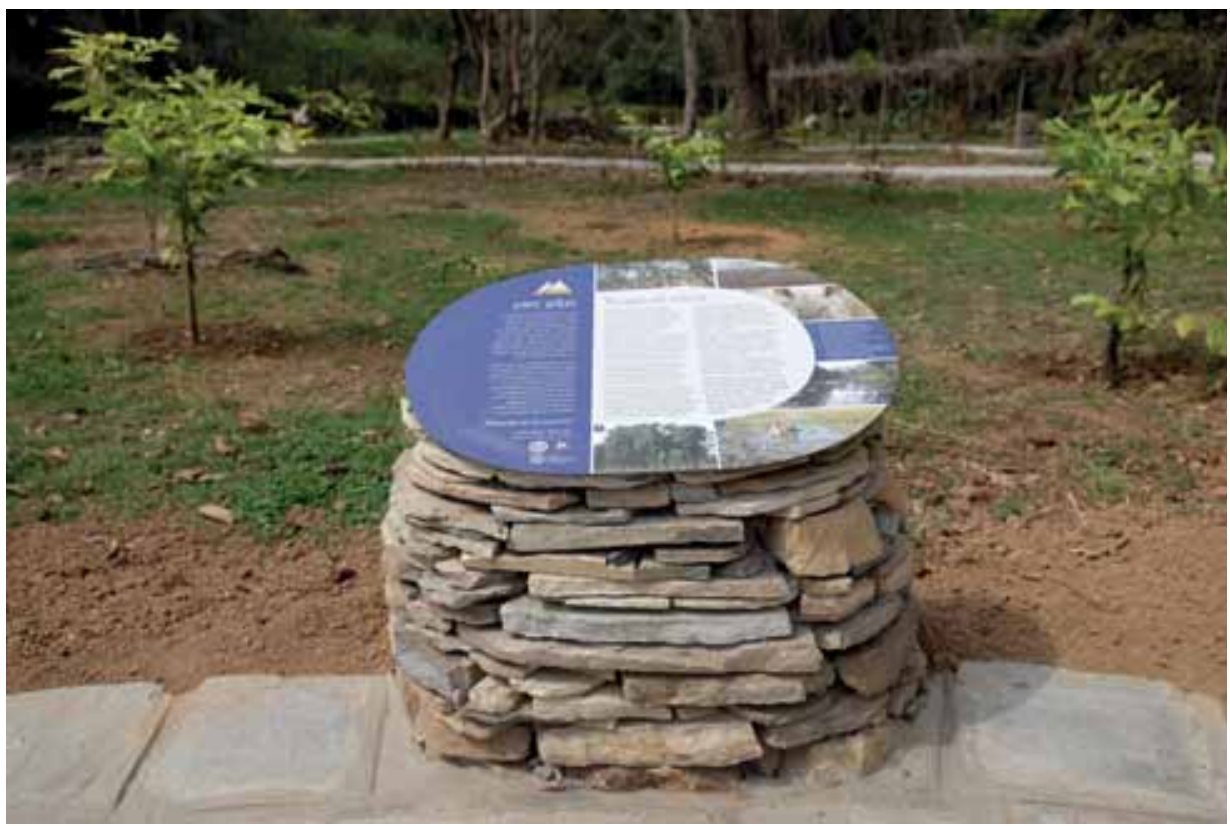

Fig. 13 Information sign for the tropical zone in the BEG. Photo: Nye Hughes. 
from Phulchowki mountain and made a nursery holding area for sowing and maintaining plants destined for the BEG (Figs 14-17). In November 2015, the District Forest Office granted permission for the removal of 19 over-mature Alnus nepalensis trees, which were up to $40 \mathrm{~m}$ tall and shading out the area and limiting new planting possibilities. The next month, these were removed by Nepalese contractors, and RBGE and NBG staff continued to collect and maintain plants for replanting in the BEG area (Fig. 18).

From January to March 2016, the hard landscaping, path and irrigation construction work was carried out and planting beds were created. Interpretation panels and posts were written, designed and produced during this time. The panels are mounted on sturdy posts made of Shorea robusta (sal) wood, a popular and extremely durable timber in the family Dipterocarpaceae which is widely used in many parts of Nepal and India for practical and decorative construction. Stone cairns with British and Nepalese design influences were made to support the ecological zone signs, and a painted brick wall was built at the entrance announcing the entry to the BEG and providing information along with a map of the area. Creation of the new planting beds, soil improvement, planting, mulching and labelling started in January and continued until March 2016, when the BEG was opened to the public (Fig. 19).

Since opening in March 2016 there has been a noticeable increase in visitor numbers - both those who visit the NBG as a whole and those who choose to walk through the BEG area. In July-October 2015, a total of 6,670 students and school pupils visited NBG, while in the same four-month period the following year, the number increased to 13,838 . The BEG is a learning resource and this is the target audience of the interpretation (Fig. 20). Feedback to NBG staff from the visiting public about their experiences of the BEG has been extremely positive.

\section{A VIEW TO THE FUTURE}

The BEG is intended to be a foundation on which future projects can be built. Just one outcome of the project has been increased links between the NBG and RBGE, so we hope that mutual benefits will continue to develop from this relationship. Primary-level teaching materials will be developed in 2017 for use by visiting schools so that teachers will be able to guide pupils around the garden and make use of the interpretation boards. The Physic Garden adjacent to the BEG and the Alpine Glasshouse in the Special Garden are also now in need of rejuvenation. These areas could offer an ideal educational resource and an opportunity for more interpretation about the plants which are so important in Nepalese life.

Other plans in the wider garden include the construction of new administration buildings. The current office buildings were badly damaged by the 2015 earthquake. The NBG has developed immensely in recent years and with appropriate allocation of resources can improve even further as a resource and significant visitor attraction in the Kathmandu Valley in the future. 


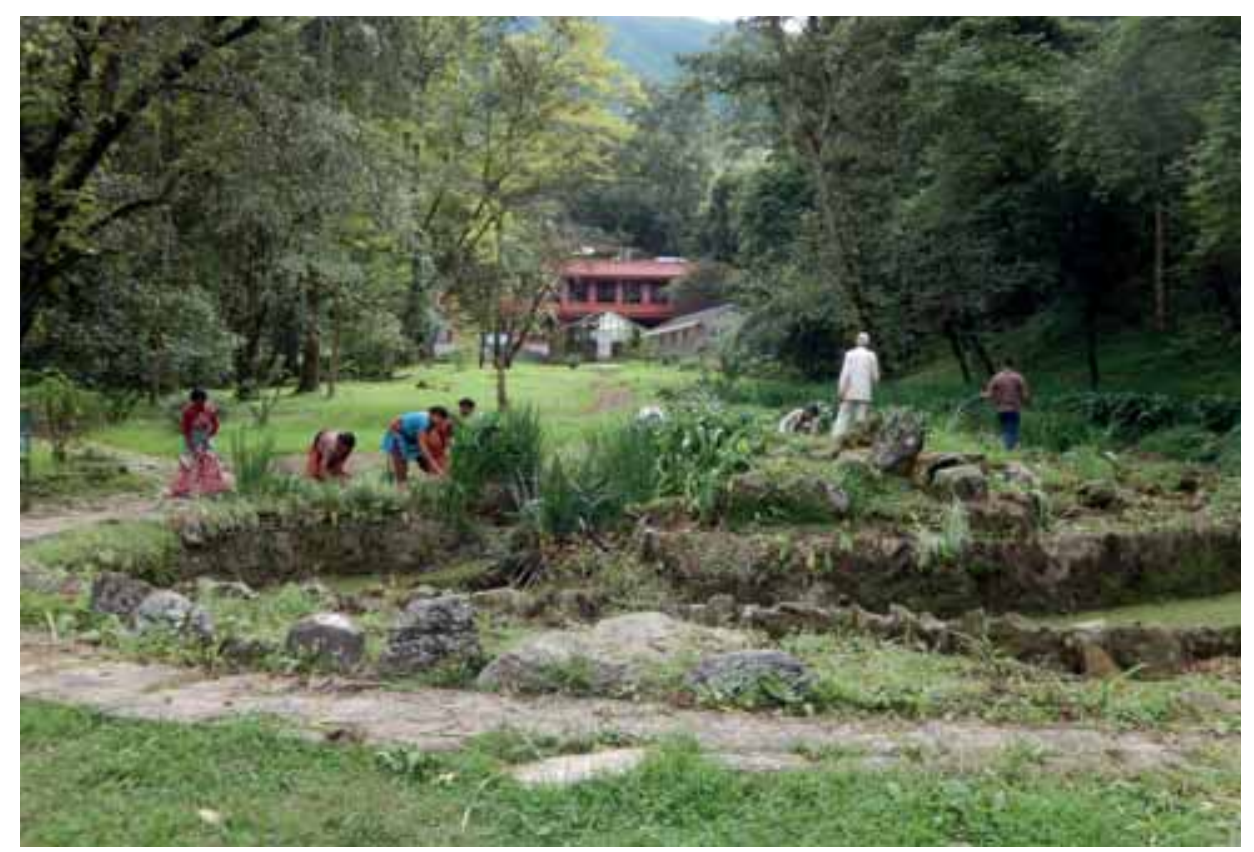

Fig. 14 Removal of non-native plants in the BEG. The new path system was marked out by spraying the grass with herbicide and this can be seen in the centre of the photo. Photo: Neil Davidson.

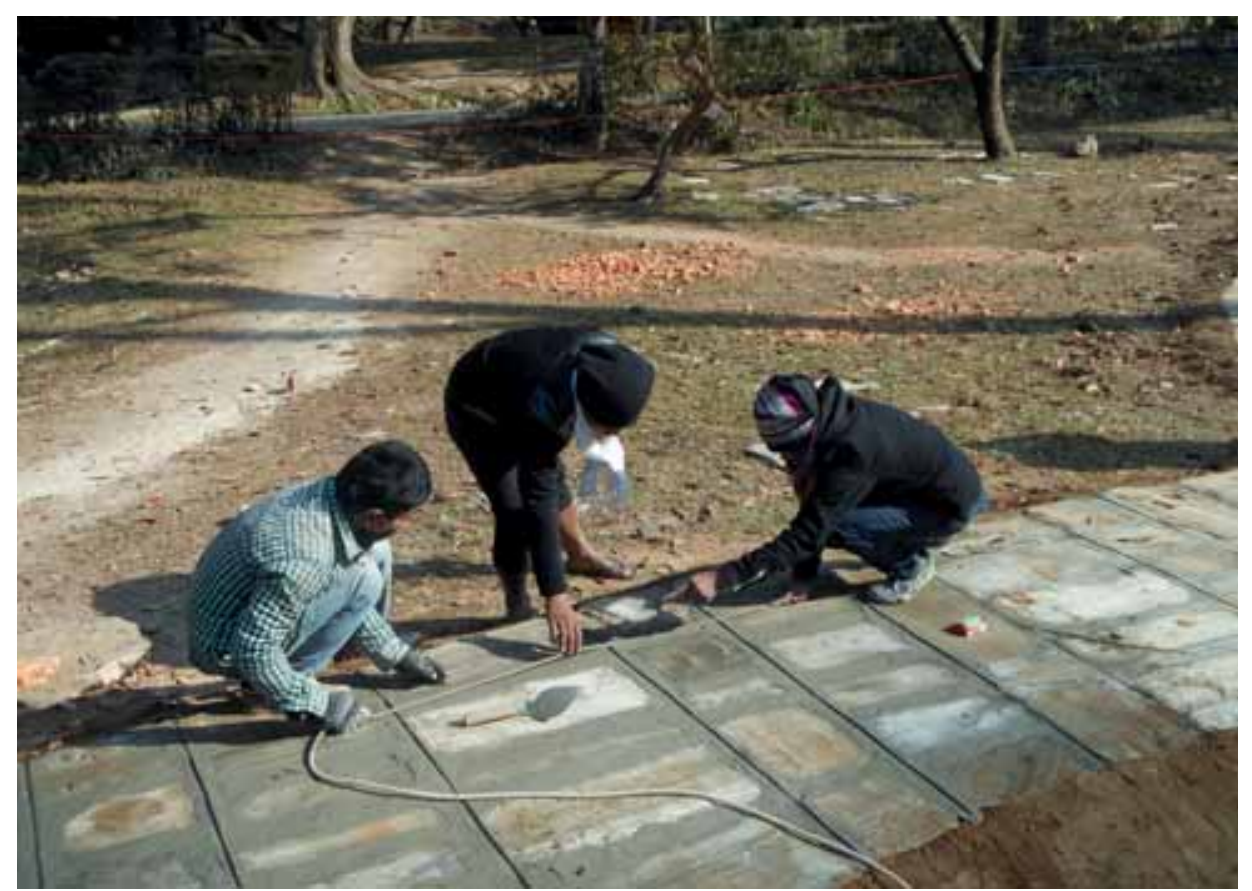

Fig. 15 Making new paths suitable for wheelchairs. Photo: Kate Hughes. 


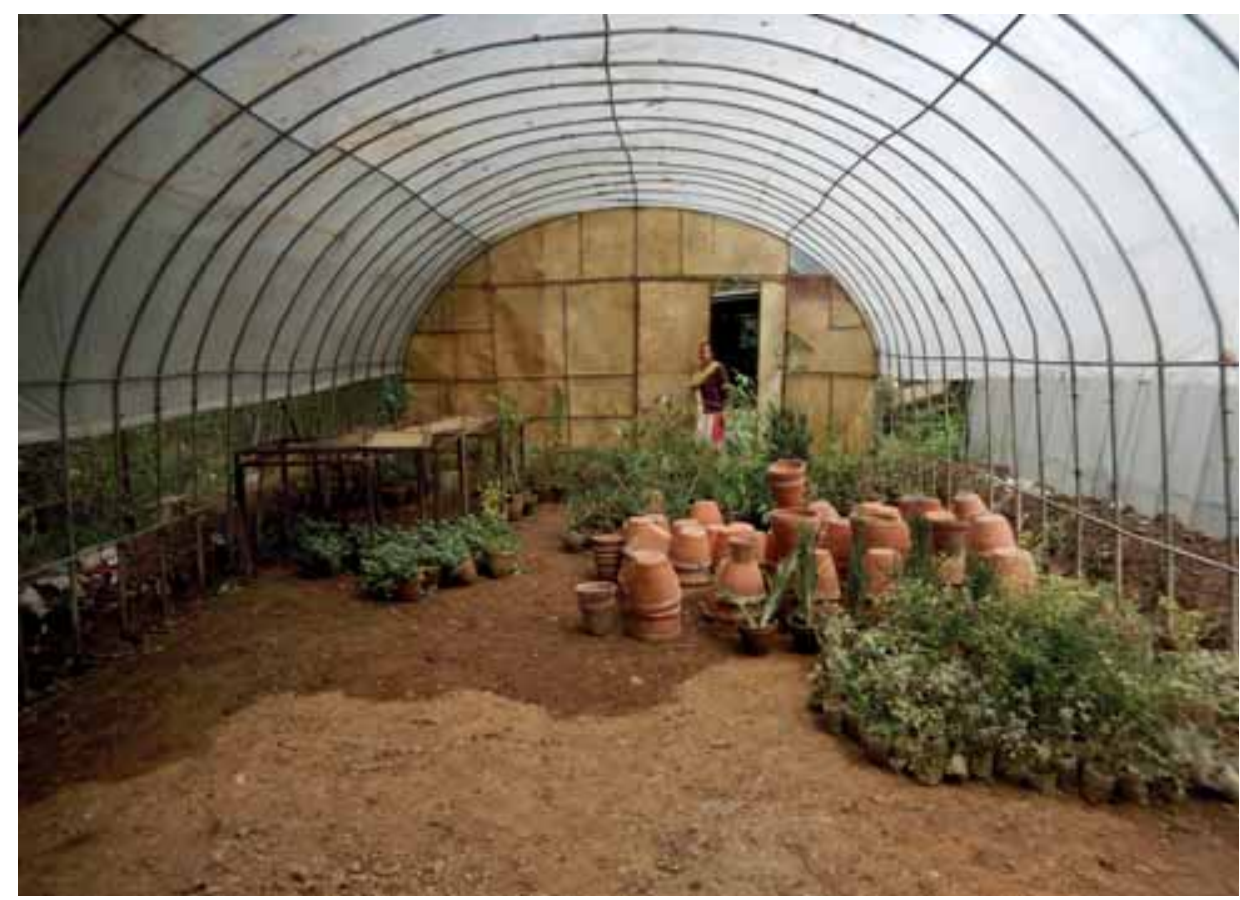

Fig. 16 Creating a holding area for plants to be brought on while the garden is being made. Photo: Neil Davidson.

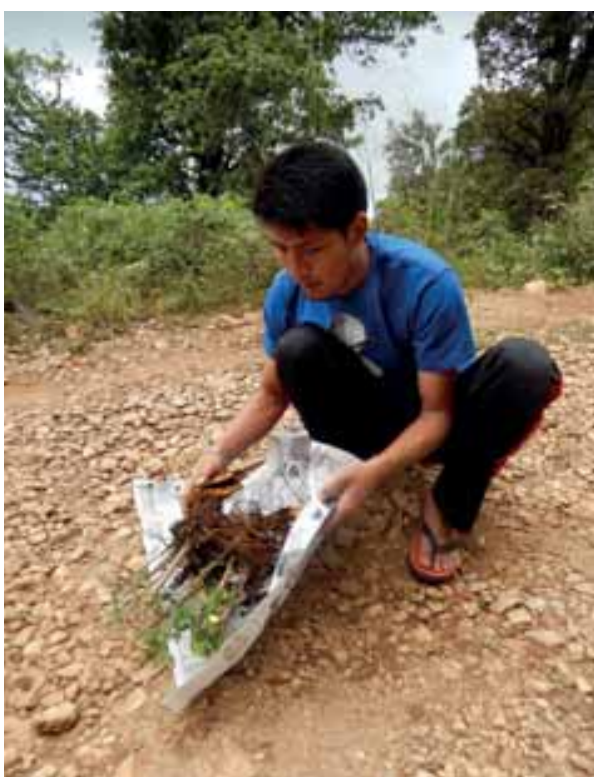

Fig. 17 Collecting plants locally on Phulchowki mountain for the BEG. Photo: Neil Davidson.

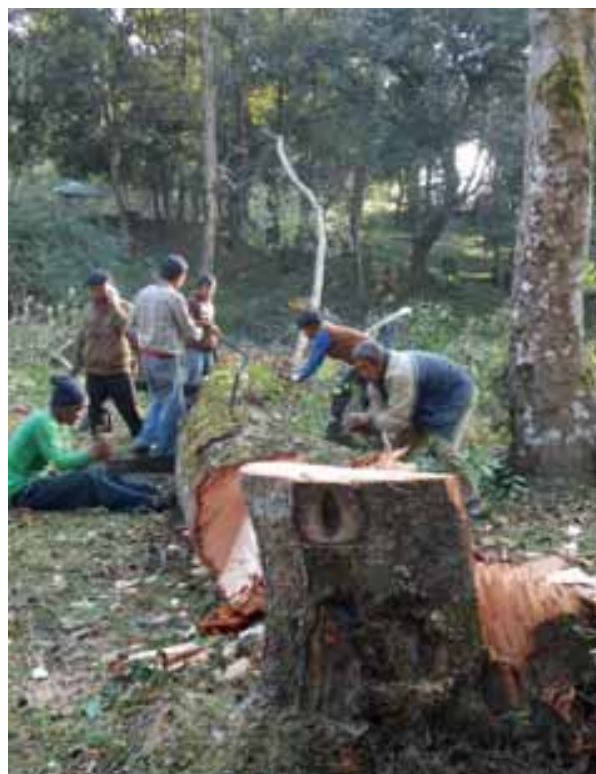

Fig. 18 Nineteen Alnus nepalensis trees were felled in the BEG with an axe and three pull saws to make space and light for new plantings. Photo: Kate Hughes. 


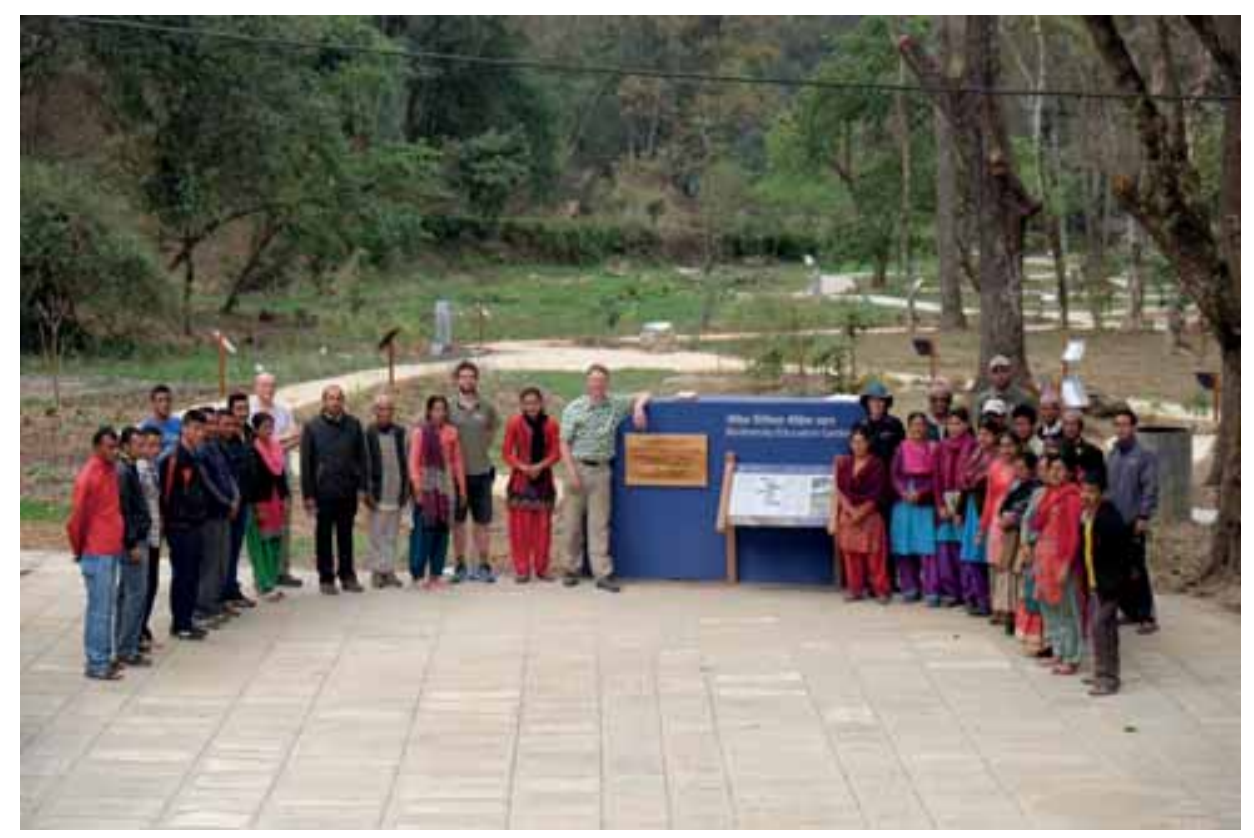

Fig. 19 Opening of the BEG with staff of the NBG and RBGE along with local contractors and craftsmen, March 2015. Photo: Nye Hughes.

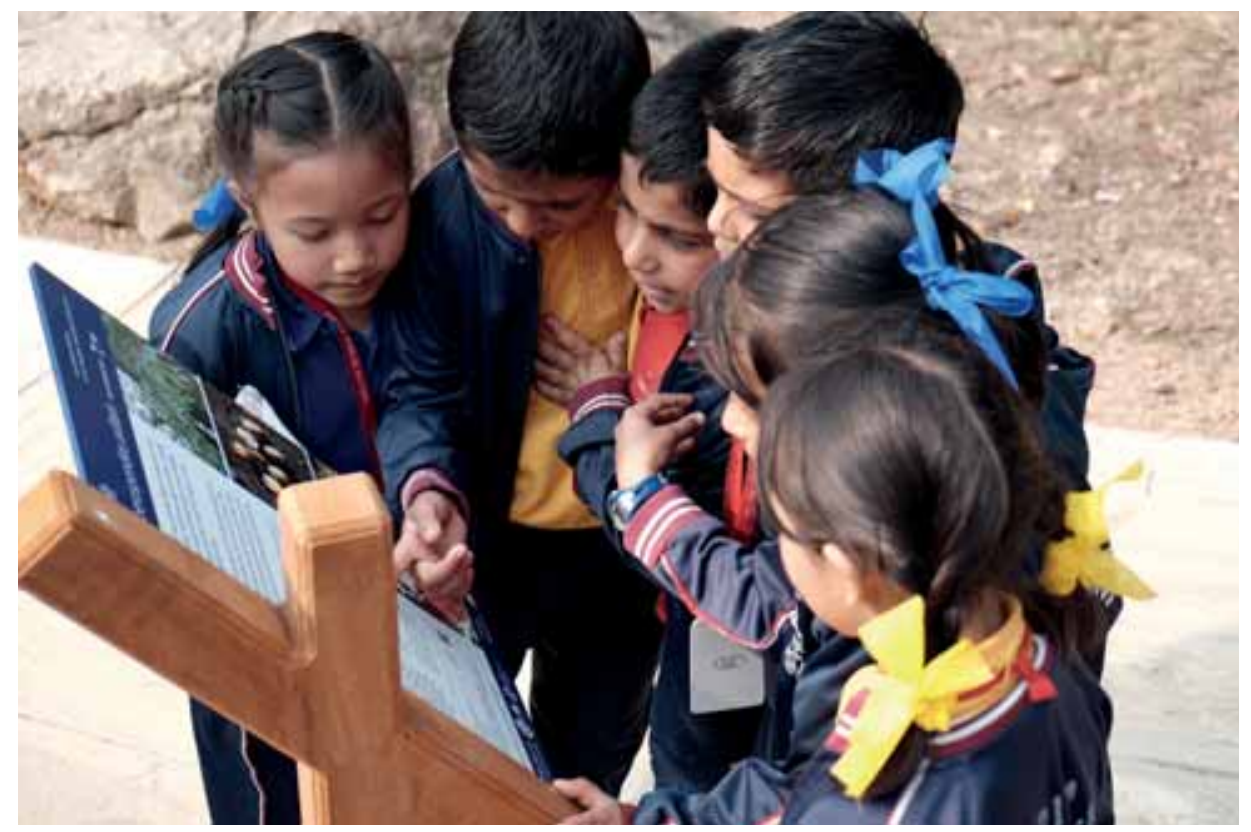

Fig. 20 Visitor numbers for the BEG are high, many of them schoolchildren. Photo: Nye Hughes. 


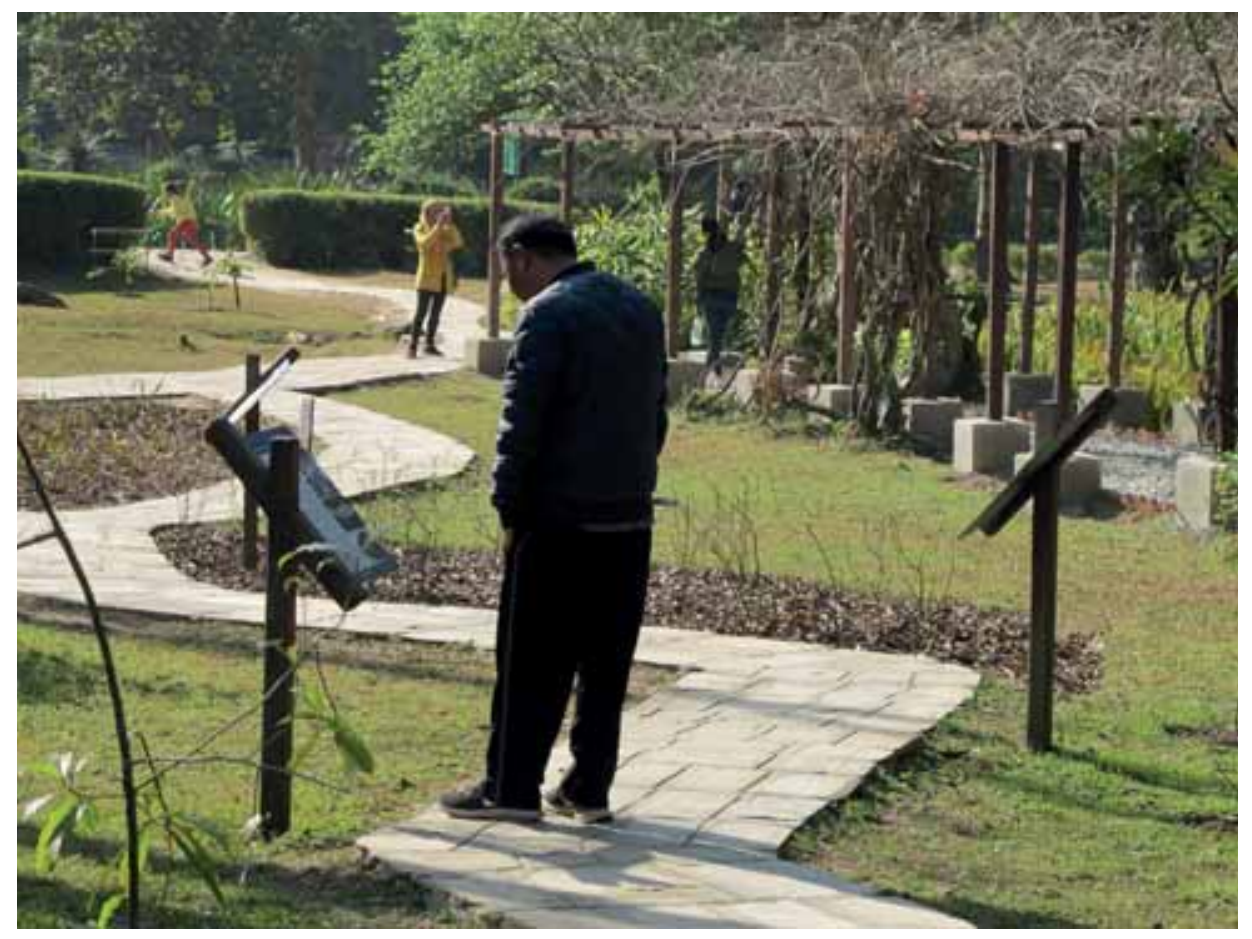

Fig. 21 Eighteen months after opening the BEG provides a place for visitors to stroll through and learn about the flora of Nepal on the way. Photo: Colin Pendry.

\section{REFERENCES}

BIODIVERSITY EDUCATION GARDEN (2016). Available online: http://beg.dpr.gov.np/ (accessed February 2017).

HOLTTUM, R.E. (1986). Obituary Dr G.A.C. Herklots CBE VMH. The Orchid Review, 94(1112), 197.

MANANDAR, N.P. (2002). Plants and People of Nepal. Timber Press, Portland, OR.

MORRIS, L. \& COHEN, L. (2010). The development of the Royal Botanic Garden Edinburgh 'Certificate in Practical Horticulture'. Sibbaldia, 8, 165-178.

POLUNIN, O. \& STAINTON, A. (2014). Flowers of the Himalaya. Oxford University Press, New Delhi.

PRESS, J.R., SHRESTHA, K.K. \& SUTTON, D.A. (2000). Annotated Checklist of the Flowering Plants of Nepal. Natural History Museum, London. Also available online as: Annotated Checklist of the Flowering Plants of Nepal (2016), www.efloras.org/flora_page. aspx?flora_id=110 (accessed February 2017).

RBGE (2014). Flora of Nepal. Available online: www.floraofnepal.org/page/home (accessed January 2017).

RBGE (2017). Available online: www.rbge.org.uk (accessed February 2017). 
SCHILLING, A.D. (1968). Royal Botanic Gardens, Nepal. Gardeners Chronicle, 64(8), 12-14.

SHARMA, I. (2003). Royal Botanical Gardens Godavari. IUCN - The World Conservation Union, Kathmandu, Nepal.

\section{APPENDICES}

\section{Appendix 1}

Plants in the BEG which are labelled but are not accompanied by detailed information panels. Some of the species listed here are also listed in Appendix 2 because they are planted in more than one location within the BEG.

Distribution and altitude information from a range of sources: Manandar, 2002; Polunin \& Stainton, 2014; RBGE, 2014; Annotated Checklist of the Flowering Plants of Nepal, 2016.

\begin{tabular}{|c|c|c|c|c|}
\hline Scientific name & Local name & Family & Distribution & $\begin{array}{l}\text { Altitude in } \\
\text { Nepal (m) }\end{array}$ \\
\hline $\begin{array}{l}\text { Rauvolfia } \\
\text { verticillata }\end{array}$ & & Apocynaceae & $\begin{array}{l}\text { Sri Lanka, Thailand, Yunnan } \\
\text { Indonesia }\end{array}$ & 1,700 \\
\hline Ilex excelsa & Puwale & Aquifoliaceae & Tropical Himalaya; in Nepal C & $600-2,100$ \\
\hline Caryota urens & Jagar palm & Arecaceae & Assam, Nepal, India, Burma, Malaya & Up to 1,200 \\
\hline $\begin{array}{l}\text { Trachycarpus } \\
\text { martianus }\end{array}$ & & Arecaceae & Nepal & 1,500 \\
\hline $\begin{array}{l}\text { Berberis } \\
\text { aristata }\end{array}$ & Chutro & Berberidaceae & $\begin{array}{l}\text { Himalaya (Garwal to Bhutan), } \\
\text { Assam, China (Yunnan); in Nepal } \\
\text { W, C \& E }\end{array}$ & $1,800-3,500$ \\
\hline $\begin{array}{l}\text { Mahonia } \\
\text { napaulensis }\end{array}$ & $\begin{array}{l}\text { Jamane } \\
\text { mandro }\end{array}$ & Berberidaceae & Nepal W \& E & $2,000-2,900$ \\
\hline Betula alnoides & Lekh painu & Betulaceae & $\begin{array}{l}\text { Himalaya (Kumaun to Bhutan), } \\
\text { Assam, S Tibet; in Nepal W, C \& E }\end{array}$ & $1,500-2,700$ \\
\hline $\begin{array}{l}\text { Sarcococca } \\
\text { coriacea }\end{array}$ & Phitphiya & Buxaceae & $\begin{array}{l}\text { Himalaya (Simla to Nepal, Assam, } \\
\text { N Burma), Afganistan; in Nepal E, } \\
\text { C \& W }\end{array}$ & $600-1,800$ \\
\hline $\begin{array}{l}\text { Valeriana } \\
\text { jatamansi }\end{array}$ & Sugandhawal & Caprifoliaceae & In Nepal & $1,500-3,600$ \\
\hline Carex baccans & & Cyperaceae & In Nepal W, C \& E & $200-2,700$ \\
\hline $\begin{array}{l}\text { Dipsacus } \\
\text { inermis }\end{array}$ & Ban karyal & Dipsacaceae & $\begin{array}{l}\text { Bhutan, India, Pakistan, Myanmar, } \\
\text { Nepal }\end{array}$ & $1,400-4,100$ \\
\hline $\begin{array}{l}\text { Ephedra } \\
\text { gerardiana }\end{array}$ & Somlata & Ephedraceae & In Nepal C\&W & $2,400-5,000$ \\
\hline $\begin{array}{l}\text { Gaultheria } \\
\text { fragrantissima }\end{array}$ & Dhasingre & Ericaceae & Himalaya; in Nepal E, C \& W & $1,200-2,700$ \\
\hline $\begin{array}{l}\text { Gaultheria } \\
\text { nummularioides }\end{array}$ & Kali gedi & Ericaceae & $\begin{array}{l}\text { Himalaya (Garhwal to Bhutan); in } \\
\text { Nepal C \& E }\end{array}$ & $2,400-4,100$ \\
\hline Pieris formosa & Lekh angeri & Ericaceae & $\begin{array}{l}\text { Himalaya (Nepal to Bhutan), N } \\
\text { Assam, Burma; in Nepal C \& E }\end{array}$ & $2,100-3,300$ \\
\hline
\end{tabular}




\begin{tabular}{|c|c|c|c|c|}
\hline Scientific name & Local name & Family & Distribution & $\begin{array}{l}\text { Altitude in } \\
\text { Nepal (m) }\end{array}$ \\
\hline $\begin{array}{l}\text { Cassia } \\
\text { floribunda }\end{array}$ & Chinchine & Fabaceae & Nepal W, C \& E & $700-2,200$ \\
\hline Juglans regia & Sano okhar & Juglandaceae & $\begin{array}{l}\text { China, SW Asia to Himalaya, SE } \\
\text { Europe }\end{array}$ & $1,500-3,000$ \\
\hline $\begin{array}{l}\text { Cinnamomum } \\
\text { camphora }\end{array}$ & Kapur & Lauraceae & $\begin{array}{l}\text { Himalaya (Kumaun, Nepal), } \\
\text { Khasia Burma, Malay \& China; in } \\
\text { Nepal C \& E }\end{array}$ & $2,100-2,600$ \\
\hline $\begin{array}{l}\text { Chlorophytum } \\
\text { nepalense }\end{array}$ & Seto musli & Liliaceae & $\begin{array}{l}\text { Himalaya (Nepal to Burma), } \\
\text { Assam }\end{array}$ & $1,500-3,000$ \\
\hline $\begin{array}{l}\text { Ficus } \\
\text { benjamina }\end{array}$ & Svami & Moraceae & $\begin{array}{l}\text { Not native to Nepal; occurs in } \\
\text { Nepal E, C \&W }\end{array}$ & up to 1,200 \\
\hline $\begin{array}{l}\text { Myrica } \\
\text { esculenta }\end{array}$ & Kafal & Myricaceae & $\begin{array}{l}\text { Sub-tropical Himalaya; in Nepal } \\
\text { C \& W }\end{array}$ & $1,000-2,300$ \\
\hline $\begin{array}{l}\text { Myrsine } \\
\text { capitellata }\end{array}$ & Seto baklepat & Myrsinaceae & East Himalaya & $900-1,800$ \\
\hline $\begin{array}{l}\text { Syzygium } \\
\text { jambos }\end{array}$ & Gulab jamun & Myrtaceae & $\begin{array}{l}\text { Planted in tropical Himalaya; in } \\
\text { Nepal C \& E }\end{array}$ & $600-1,400$ \\
\hline $\begin{array}{l}\text { Jasminum } \\
\text { humile }\end{array}$ & Jaee & Oleaceae & $\begin{array}{l}\text { Himalaya, Afghanistan, Tibet, } \\
\text { Burma, W China; in Nepal E, C } \\
\text { \& W }\end{array}$ & $1,100-3,800$ \\
\hline $\begin{array}{l}\text { Pinus } \\
\text { roxburghii }\end{array}$ & Rani sallo & Pinaceae & Himalaya; in Nepal E, C \&W & $2,000-2,200$ \\
\hline $\begin{array}{l}\text { Pinus } \\
\text { wallichiana }\end{array}$ & Gobre sallo & Pinaceae & In Nepal E, C \& W & $1,600-3,300$ \\
\hline $\begin{array}{l}\text { Podocarpus } \\
\text { neriifolius }\end{array}$ & Gunsi & Podocarpaceae & $\begin{array}{l}\text { Tropical Himalaya (Nepal to } \\
\text { Sikkim), Burma, Sumatra, Borneo, } \\
\text { Malay Peninsula, Andaman Islands }\end{array}$ & $900-1,300$ \\
\hline $\begin{array}{l}\text { Anemone } \\
\text { vitifolia }\end{array}$ & Maaure mulo & Ranunculaceae & $\begin{array}{l}\text { Himalaya (Kashmir to NEFA), N } \\
\text { Assam, N Burma, W China }\end{array}$ & $1,300-3,300$ \\
\hline $\begin{array}{l}\text { Prunus } \\
\text { cerasoides }\end{array}$ & Paiyun & Rosaceae & $\begin{array}{l}\text { Temperate Himalaya (Garwal to } \\
\text { Sikkim \& Bhutan); in Nepal W, } \\
\text { C \& E }\end{array}$ & $1,300-2,400$ \\
\hline $\begin{array}{l}\text { Pyracantha } \\
\text { crenulata }\end{array}$ & Gangharu & Rosaceae & $\begin{array}{l}\text { Temperate Himalaya; in Nepal E, } \\
\mathrm{C} \& \mathrm{~W}\end{array}$ & $1,200-2,500$ \\
\hline $\begin{array}{l}\text { Zanthoxylum } \\
\text { armatum }\end{array}$ & Timur & Rutaceae & Nepal W, C \& E & $1,500-2,400$ \\
\hline Acer oblongum & Phirphire & Sapindaceae & $\begin{array}{l}\text { Himalayan (Kasmir to Bhutan), } \\
\text { Assam, Burma, Indo-China; in } \\
\text { Nepal W \& C }\end{array}$ & $1,200-2,400$ \\
\hline $\begin{array}{l}\text { Taxus } \\
\text { wallichiana }\end{array}$ & Lauth salla & Taxaceae & In Nepal E \&W & $2,300-3,400$ \\
\hline $\begin{array}{l}\text { Hedychium } \\
\text { spicatum }\end{array}$ & Seto saro & Zingiberaceae & $\begin{array}{l}\text { Yunnan, Bhutan, NE India, Sikkim, } \\
\text { Thailand; in Nepal }\end{array}$ & $1,800-2,800$ \\
\hline $\begin{array}{l}\text { Roscoea } \\
\text { purpurea }\end{array}$ & Bhuisaro & Zingiberaceae & Himalaya & $1,500-3,000$ \\
\hline
\end{tabular}




\section{Appendix 2}

Plants in the BEG with bilingual information panels describing the names, habitats, uses and other information about the species (see Fig. 12).

\begin{tabular}{|c|c|c|c|}
\hline Scientific Name & Local Name & Family & Altitude in Nepal (m) \\
\hline Saurauia napaulensis & Gogan & Actinidiaceae & $750-2,100$ \\
\hline Choerospondias axillaris & Lapsi & Anacardiaceae & $950-1,900$ \\
\hline Rauvolfia serpentina & Sarpaganda & Apocynaceae & $100-900$ \\
\hline Berberis asiatica & Chutro & Berberidaceae & $1,000-2,700$ \\
\hline Mahonia napaulensis & Jamane mandro & Berberidaceae & $1,220-1,900$ \\
\hline Bombax ceiba & Simal & Bombacaceae & $200-900$ \\
\hline Valeriana jatamansii & Sugandhwal & Caprifoliaceae & $1,500-3,300$ \\
\hline Elaeocarpus sphaericus & Rudraksha & Eleaocarpaceae & $700-1,700$ \\
\hline Ephedra gerardiana & Somlata & Ephedraceae & $2,300-5,200$ \\
\hline Rhododendron arboreum & Lali gurans & Ericaceae & $1,500-3,600$ \\
\hline Cinnamomum tamala & Tejpat & Lauraceae & $450-2,000$ \\
\hline Dalbergia sissoo & Sissoo & Leguminosae & $200-1,400$ \\
\hline Bauhinia variegata & Koiralo & Leguminosae & $150-1,900$ \\
\hline Piptanthus nepalensis & Suga phul & Leguminosae & $1,200-4,200$ \\
\hline Toona ciliata & Tuni & Meliaceae & $200-1,700$ \\
\hline Nyctanthes arbor-tristis & Parijat & Oleaceae & $150-2,000$ \\
\hline Dendrobium densiflorum & Sungava & Orchidaceae & $900-2,900$ \\
\hline Pinus wallichiana & Gobre salla & Pinaceae & $1,300-4,100$ \\
\hline Abies spectabilis & Talispatra & Pinaceae & $2,000-4,400$ \\
\hline Thysanolaena latifolia & Amliso & Poaceae & $300-2,000$ \\
\hline Murraya koenigii & Mitho nim & Rutaceae & $150-1,450$ \\
\hline Zanthoxylum armatum & Timur & Rutaceae & $1,000-3,000$ \\
\hline Astilbe rivularis & Thulo Aaushdhi & Saxifragaceae & $2,000-3,500$ \\
\hline Bergenia ciliata & Pakhan bhed & Saxifragaceae & $1,300-3,200$ \\
\hline Taxus wallichiana & Lauth salla & Taxaceae & $2,300-3,500$ \\
\hline
\end{tabular}

